\title{
KONTINUITAS pOLA PEWARISAN SENI MENENUN SONGKET DI NAgARI PANDAI SIKEK, TANAH DATAR
}

\author{
Oleh Eny Christyawaty
}

Balai Arkeologi Medan

Jl. Seroja Raya Gang. Arkeologi No. 1, Medan Tuntungan, Medan

Telp. 061-8224365/fax. 061-8224363

Email:enychw@ymail.com

Naskah diterima: 13 Maret 2011

Naskah disetujui: 31 Mei 2011

\begin{abstract}
Abstrak
Tulisan ini bertujuan untuk mengetahui kontinuitas pola pewarisan seni menenun songket di Nagari Pandai Sikek dan ingin mengetahui siapa saja yang terlibat dalam pewarisan seni menenun tersebut. Keahlian menenun songket bukanlah sesuatu yang didapat begitu saja tetapi merupakan sesuatu yang harus dipelajari. Penelitian ini menggunakan metode kualitatif. Hasil penelitian menunjukkan bahwa keahlian menenun songket ini hingga sekarang masih bertahan pada masyarakat Pandai Sikek. Agen penting dalam proses pewarisan seni menenun ini adalah keluarga dan warga asli Pandai Sikek. Pewarisan seni menenun (transfer of skill) ini dalam prosesnya memerlukan pembelajaran yang membutuhkan waktu berbulan-bulan bahkan bertahun-tahun hingga seseorang menguasai keterampilan tersebut. Selain itu terdapat persyaratan yang disebut mahar yang hingga kini masih berlaku.
\end{abstract}

Kata kunci: seni menenun, songket, pola, pewarisan

\section{Abstract}

This paper aims to investigate the continuity of pattern in transferring songket-weaving skill in Nagari Pandai Sikek as well as tracing persons involved in the process. Weaving songket is a kind of skill that must be learnt. A qualitative research method was used in this research to depict a deep social reality. The result shows that the skill is still preserved in Pandai Sikek society. Families and indigenous people of Pandai Sikek play as important agents in the process of transferring the skill. The skill takes months, even years to be mastered. Besides, there is a requirement that must be fulfilled called mahar.

Keywords: weaving art, songket, pattern, transfer of skill. 


\section{A. PENDAHULUAN}

Songket sering disebut "ratunya kain tenun", karena songket memiliki keindahan dan kemewahan tenunan yang dibuat dari benang emas atau perak yang terkesan gemerlap. Secara teknis, kain songket ditenun dengan menganyamkan benang pakaian dan benang motif berwarna emas pada kain helai benang lungsin(benang yang membujur pada benang tenunan) yang melintang pada alat yang yang disebut panta (Bart, 2006:17).Dengan kata lain, kain songket merupakan perpaduan antara kreativitas dan kecerdasan dalam mengekspresikan wujud keindahan.

Keahlian menenun songket bukanlah sesuatu yang didapat begitu saja tetapi merupakan sesuatu yang harus dipelajari. Kain tenun songket Minangkabau sebenarnya sudah ada lebih dari seratus tahun yang lalu. Hal ini memperlihatkan Minangkabau memiliki kualitas produk budaya yang patut dibanggakan. Artinya, Minangkabau pernahmencapaisuatufaseperkembangan yang mampu menciptakan karya budaya melewati zamannya (Utama, 2006:6).

Salah satu nagari di ranah Minang yang merupakan sentra penghasil tenunan songket adalah Nagari Pandai Sikek. Pandai Sikek adalah salah satu kenagarian yang berada di kaki Gunung Singgalang dan secara administratif termasuk dalam Kecamatan X Koto, Kabupaten Tanah Datar, Provinsi Sumatra Barat. Keterampilan menenun songket sampai saat ini masih dilakukan, bukan hanya oleh ibu-ibu, tapi juga para gadis di sela-sela kesibukan belajar (sekolah) untuk mengisi waktu luangnya.

Di tengah arus modernisasi dan perkembangan teknologi yang sangat pesat, keterampilan menenun songket di wilayah Nagari Pandai Sikek hingga sekarang masih eksis. Hal ini menarik dikaji, sehubungan dengan pembuatannya yang rumit serta memakan waktu yang relatif lama, yaitu berminggu-minggu, bahkan berbulan-bulan, selain itu juga tingginya persaingan dengan kain pabrik (yang dibuat dengan alat mesin modern). Dizaman serbapabrikasi sepertisekarang, termasuk dalam pembuatan kain untuk pakaian, ternyata pembuatan kain dengan menggunakan keterampilan tangan dan alat sederhana dalam menenun masih ada dan tetap bertahan hingga saat ini.

Perubahan zaman sebenarnya memungkinkan menenun dengan menggunakan mesin yang hasilnya lebih cepat dan secara kuantitas lebih banyak dibandingkan dengan peralatan tradisional. Songket hasil tenunan dari Nagari Pandai Sikek termasuk jenis tradisional karena masih menggunakan ATBM (alat tenun bukan mesin). Secara keseluruhan alat yang digunakan untuk menenun disebut dengan panta. Panta ini terbuat dari kayu dan sampai sekarang alat ini masih digunakan oleh para penenun karena lebih dapat menghasilkan motifmotif yang lebih variatif dibandingkan dengan peralatan yang mesin. Menenun dengan ATBM (alat tenun bukan mesin) membutuhkan keahlian khusus yang harus dipelajari dalam waktu yang tidak sebentar, juga membutuhkan kesabaran, kecermatan, dan stamina yang bagus. Hal ini menimbulkan pertanyaan penelitian tentang: bagaimana cara mereka mewariskan keahlian seni menenun dari generasi ke generasi dan siapa sajakah yang terlibat dalam proses pewarisan tersebut?

Tulisan ini bertujuan mengetahui kontinuitas pola pewarisan seni menenun songket di Nagari Pandai Sikek, selain 
itu juga ingin mengetahui siapa saja yang terlibat dalam pewarisan seni menenun tersebut. Penelitianini menggunakan metode kualitatif supaya gambaran tentang realitas sosial dapat digali lebih mendalam. Analisis kualitatif merupakan usaha untuk mencapai pengertian tentang suatu gejala sosial dengan menggunakan data. Teknik pengumpulan data dilakukan dengan pengamatan langsung di lapangan (observasi), wawancara, studi kepustakaan. Data primer diperoleh melalui wawancara mendalam dengan informan kunci (key informan), seperti: para penenun yang senior maupun penenun yang masih dalam proses belajar, tokoh-tokoh masyarakat (wali nagari). Pengamatan langsung di lapangan diperlukan untuk mengetahui kondisi lokasi daerah penelitian. Studi pustaka dilakukan dengan mempelajari literaturliteratur yang menunjang penelitian.

Seni (art) merupakan keahlian dan keterampilan manusia untuk mengekspresikan dan menciptakan hal-hal yang indah serta bernilai (Koentjaraningrat et al., 2003:214). Definisi yang lain mengatakan bahwa seni merupakan penggunaan kreatif imajinasi manusia untuk menerangkan, memahami, dan menikmati kehidupan. Meskipun gagasan tentang seni untuk tujuan yang tidak berguna dan tidak praktis tampaknya tertanam dalam-dalam pada pemikiran orang Barat modern, dalam kebudayaan-kebudayaan lain seni sering digunakan untuk keperluan yang dianggap penting dan praktis (Haviland 1988:223). Salah satu kesenian yang dimiliki oleh masyarakat Nagari Pandai Sikek dan sudah ada sejak dulu adalah seni menenun (weaving). Dengan kata lain, keahlian dan keterampilan ini merupakan warisan dari nenek moyang secara turun menurun. Hal ini sudah terjadi berulang-ulang hingga membentuk suatu pola. Pola merupakan rangkaian unsur yang mantap dari suatu gejala sehingga dapat dipakai sebagai contoh dalam hal menggambarkan dan mendeskripsikan gejala (Koentjaraningrat et al., 2003: 192). Untuk mendapatkan warisan seni ini tentu saja harus melalui proses pembelajaran terlebih dahulu.

Pewarisan ini umumnya dilakukan oleh seseorang yang mempunyai keahlian menenun kepada seseorang yang lain, baik secara formal atau pun nonformal. Secara formal pewarisan dapat dilakukan di sekolah atau lembaga pendidikan, sedangkan secara nonformal bisa dilakukan di mana saja, misalnya di dalam keluarga. Pewarisan keterampilan dalam keluarga sangat dimungkinkan karena keluarga merupakan tempat sosialisasi berbagai hal, termasuk sosialisasi keterampilan seni menenun. Di samping itu, keluarga merupakan kelompok primer (primary group) yang pertama bagi seseorang (anak) dan di situlah perkembangan kepribadian bermula. Ketika anak sudah cukup umur untuk memasukikelompok primer lain di luar keluarganya, pondasi dasar kepribadiannya sudah ditanamkan secara kuat (Horton, Paul B dan Hunt, Chester L, 1987: 276).

\section{B. HASIL DAN BAHASAN}

\section{Deskripsi Wilayah}

Pandai Sikek adalah salah satu kenagarian di Kecamatan X (baca: Sapuluah_penulis) Koto, Kabupaten Tanah Datar, Provinsi Sumatera Barat. Nagari ini berada di kaki Gunung Singgalang, selain itu juga berhadapan 
dengan Gunung Merapi sehingga sekilas nampak bahwa nagari ini diapit oleh dua gunung. Hal ini menyebabkan topografi daerahnya menjadi bergelombang. Kondisi yang demikian menjadikan pemandangan wilayah ini justru terlihat sangat indah, hamparan sawah yang menghijau dan sebagian menguning, serta kebun sayur seperti permadani yang menutupi lembah. Begitu pula dengan sungai-sungai yang mengalir berkelokkelok mengitari nagari serta kolam-kolam ikan yang hampir ada di setiap tempat dan di halaman rumah semakin menambah kesejukan dan keindahan. Ketinggian Pandai Sikek di atas permukaan air laut (dpl) adalah sekitar 1200 Meter. Hal ini menyebabkan suhu di daerah ini menjadi sejuk, yaitu antara $25^{\circ}-30^{\circ}$ Celcius.

Jarak Nagari Pandai Sikek dengan ibu kota provinsi, yaitu Kota Padang, adalah sekitar $84 \mathrm{Km}$. Jarak ini jika ditempuh dengan kendaraan bermotor membutuhkan waktu sekitar dua jam. Sementaraituuntukkeibu kotaKabupaten Tanah Datar, yaitu Batusangkar, berjarak $40 \mathrm{Km}$. Jika ditempuh dengan kendaraan bermotor akan memakan waktu sekitar satu jam perjalanan.

Wilayah Pandai Sikek yang mempunyai luas sekitar $2.150 \mathrm{Ha}$ ini terdiri dari empat jorong ${ }^{l}$, antara lain: Koto Tinggi (luas wilayah $600 \mathrm{Ha}$ ), Tanjung (luas wilayah 700 ha), Pagupagu (luas wilayah $400 \mathrm{Ha}$ ), dan Baruah (luas wilayah $450 \mathrm{Ha}$ ). Adapun batasbatas wilayahnya adalah: sebelah utara berbatasan dengan Padang Laweh, Kabupaten Agam; sebelah selatan berbatasan dengan Koto Laweh, Kabupaten Tanah Datar; sebelah barat berbatasan dengan Gunung Singgalang;

1 Jorong adalah kesatuan wilayah di bawah nagari. dan sebelah timur berbatasan dengan Nagari Koto Baru dan Nagari Koto Laweh, Kabupaten Tanah Datar.

WargaPandaiSikekyangberjumlah 55.223 jiwa bisa dikatakan homogen karena sebagian besar atau sekitar 98 persen penduduknya adalah anak nagari ${ }^{2}$ atau urang awak yang merupakan orang Minangkabau.Mata pencaharian warga secara umum bervariasi, antara lain: ada buruh tani, petani, pedagang, wiraswasta, pengusaha, perajin ukiran, perajin tenun, pegawai negeri sipil (PNS), penjahit, montir, sopir, karyawan swasta, tukang kayu, tukang batu, guru swasta (seperti terlihat pada tabel 1).

Nagari ini merupakan daerah agraris yang subur, oleh karena itu tidak mengherankan jika sebagian besar masyarakatnya bermatapencaharian sebagai petani (40 persen lebih).

Mata pencaharian sebagai pedagang, wiraswasta, serta pengusaha merupakan pekerjaan juga yang banyak dipilih oleh warga setempat, yaitu ada sekitar 25 persen. Selain itu sebagian lagi masyarakat berprofesi sebagai perajin, yaitu ada sekitar 23 persen. Banyaknya penduduk yang berprofesi ini bisa dimengerti karena di nagari ini merupakan sentra kerajinan tenun dan kerajinan ukiran, sehingga Pandai Sikek dikenal masyarakat luas sebagai penghasil tenun songket di samping ukir-ukiran. Para perajin ini tersebar di semua jorong. Selain itu ada juga warga yang berprofesi sebagai pengusaha yang mempunyai rumah tenun atau gallery yang menjual berbagai macam hasil kerajinan, misalnya songket atau ukiran kayu. Sebagian menjadi induak tanun ${ }^{3}$

2 Anak nagari adalah istilah untuk orang asli atau penduduk asli.

3 Induak tanun adalah seseorang yang 
Tabel 1. Penduduk Nagari Pandai Sikek menurut

Mata Pencaharian Tahun 2008

\begin{tabular}{|c|l|c|c|}
\hline No & Mata Pencaharian & $\begin{array}{r}\text { Jum- } \\
\text { lah } \\
\text { (jiwa) }\end{array}$ & $\begin{array}{c}\text { Prosentase } \\
(\%)\end{array}$ \\
\hline 1 & Buruh Tani & 75 & 2,26 \\
\hline 2 & Petani & 1.342 & 40,5 \\
\hline 3 & $\begin{array}{l}\text { Pedagang/Wiraswasta/ } \\
\text { Pengusaha }\end{array}$ & 815 & 24,6 \\
\hline 4 & Perajin & 768 & 23,18 \\
\hline 5 & PNS & 52 & 1,57 \\
\hline 6 & TNI/POLRI & - & - \\
\hline 7 & Penjahit & 13 & 0,39 \\
\hline 8 & Montir & 20 & 0,15 \\
\hline 9 & Sopir & 19 & 0,60 \\
\hline 10 & Karyawan swasta & - & 0,57 \\
\hline 11 & Kontraktor & 93 & 2,8 \\
\hline 12 & Tukang kayu & 24 & 0,7 \\
\hline 13 & Tukang batu & 86 & 2,59 \\
\hline 14 & Guru swasta & 3.312 & 100 \\
\hline & Jumlah & & 5 \\
\hline
\end{tabular}

Sumber: Monografi Nagari Pandai Sikek Tahun 2008

(induk tenun) yang mempunyai banyak anggota atau anak buah penenun. Pekerjaan sebagai pedagang meliputi dagang hasil bumi, membuka toko, dan lain-lain.

Asal-usul nama Nagari Pandai Sikek menurut kisah yang beredar di masyarakat adalah pada zaman dahulu di daerah ini ada seorang yang bernama si Ikek yang pandai dalam hal menyisir daun pandan. Pandai Sikek sendiri menurut salah seorang warga terdiri dari dua kata, yaitu pandai dan sikek. Pandai

mempunyai banyak anak buah yang mengerjakan tenunan dengan fasilitas dari sang induak tanun.fasilitas tersebut misalnya; benang katu, benang sutera, benang emas atau perak, dan lain sebagainya. artinya pandan atau daun pandan, dan sikek artinya sisir yang dalam bahasa Minang artinya menganyam. Dengan demikian pandai sikek artinya kirakira menyisir atau menganyam daun pandan, salah satunya untuk dijadikan tikar. Keterampilan menganyam pandan inilah yang diyakini sebagai awal mula keterampilan menenun. Berdasarkan kepandaian atau keterampilan warga tersebut kemungkinan daerah ini dinamakan Pandai Sikek hingga sekarang.

\section{Pemasaran Hasil Tenunan}

Sejak akhir tahun 1970 Pandai Sikek mulai bersinar dan dikenal secara luas, bahkan para wisatawan 
mancanegara pun berdatangan ke tempat ini. Produk-produknya bukan hanya digunakan sebagai souvenir, tetapi juga untuk keperluan upacara adat. Permintaan pasar yang besar pada saat itu tidak bisa direspon dengan cepat oleh para perajin setempat karena teknologi substitusi belum ada yang mampu menggantikan alat tenun panta $^{4}$. Hingga kini pun panta masih dipertahankan oleh masyarakat setempat. Mereka belum berniat menggantikan panta dengan alat tenun lainnya, misalnya ATM (alat tenun mesin).

Pemasaran hasil tenunan songket Pandai Sikek hingga kini pusatnya masih di nagari ini, artinya masyarakat yang ingin membeli songket Pandai Sikek biasanya langsung datang ke nagari ini untuk memilih dan membeli songket yang mereka inginkan. Hal ini sesuai dengan pesan nenek moyang mereka yang ingin nagarinya maju. Dengan datangnya orang luar ke nagari ini, maka nagari ini akan semakin ramai dan semakin dikenal orang secara luas. Hal ini dimaksudkan supaya mendatangkan kemakmuran bagi anak nagari. Meskipun demikian, kini masyarakat perajin Pandai Sikek sudah banyak yang mengikuti pameranpameran seni di berbagai tempat, ke luar provinsi, bahkan ke luar negeri. Bahkan sudah ada yang membuka butik atau galeri di Jakarta dan daerah-daerah lainnya

Toko-toko atau galeri yang menjual songket hasil tenunan perajin yang ada di Nagari Pandai Sikek, antara lain sebagaimana tercantum pada tabel berikut ini.

\begin{tabular}{|l|l|l|l|l|}
\hline No & \multicolumn{1}{|c|}{$\begin{array}{c}\text { Nama Toko/ } \\
\text { Galeri }\end{array}$} & \multicolumn{1}{c|}{ Lokasi } & \multicolumn{1}{c|}{ Pemilik } & Jenis Produksi \\
\hline 1 & Lima Saudara & $\begin{array}{l}\text { Kapalo Koto, Jorong } \\
\text { Baruah }\end{array}$ & Maiata & $\begin{array}{l}\text { Tenunan songket, } \\
\text { ukiran kayu }\end{array}$ \\
\hline 2 & $\begin{array}{l}\text { Pandai Sikek } \\
\text { Accessories }\end{array}$ & $\begin{array}{l}\text { Kapalo Koto, Jorong } \\
\text { Baruah }\end{array}$ & Melfi Yamaira & $\begin{array}{l}\text { Tenunan songket, } \\
\text { ukiran kayu }\end{array}$ \\
\hline 3 & Nan Sari & Guguak Baruah & Dt. Mangkuto Kayo & Tenunan songket \\
\hline 4 & Satu Karya & Kapalo Koto Baruah & Erma Yulnita & Tenunan songket \\
\hline 5 & Limpapeh & Kapalo Koto Baruah & Marnida & Tenunan songket \\
\hline 6 & Fatimah Sayuti & Koto Tinggi & Emila Fatma & Tenuan songket \\
\hline 7 & Putri Ayu & Koto Tinggi & Nur Afni & Tenunan songket \\
\hline 8 & Ati Pinang & Koto Tinggi & Hj. Beharti & Tenunan songket \\
\hline 9 & Hj. Ratna & Koto Tinggi & Hj. Ratna & Tenunan songket \\
\hline 10 & Hj. Jalisah & Tanjuang & Hj. Jalisah & Tenunan songket \\
\hline 11 & Pusako & Kapalo Koto Baruah & Hj. Sanuar & Tenunan songket \\
\hline 12 & Pusako Minang & Jl. Baruah & Rasmi & Tenunan songket \\
\hline
\end{tabular}

$4 \quad$ Panta adalah peralatan keseluruhan untuk menenun songket yang terbuat dari kayu, alat ini bisa dikatakan masih sangat sederhana dan masih tradisional.

Toko-toko atau butik-butik yang ada di Nagari Pandai Sikek menurut data monografi nagari tercatat ada dua 
belas buah. Toko maupun butik tersebut umumnya mempunyai anak buah yang membuat tenunan songket. Anak buah tersebut biasanya membuat tenunan sesuai dengan pesanan para pemilik toko atau butik tersebut, yang biasa disebut dengan induk tanun.

Semua bahan untuk menenun disediakan oleh para induk tanun. Mereka menenun di rumah masing-masing pada umumnya dan setelah selesai hasil tenunan tersebut diserahkan kepada induk tanun-nya. Ada juga penenun yang menenun di rumah induk tanun, hanya saja jumlahnya sangat sedikit. Mereka lebih suka menenun di rumah masing-masing karena bisa sambil mengerjakan pekerjaan rumah. Dari hasil tenunan songket, para perajin songket menghasilkan jenis-jenis produk kreasi lainnya, yaitu:

1. Sisamping, yaitu jenis produk yang dipakai oleh kaum laki-laki Minangkabau, biasa digunakan sebagai kelengkapan kain penghulu. Ukurannya $80 \mathrm{~cm}$ x $200 \mathrm{~cm}$.

2. Sarung, produk kain tenunan yang biasanya digunakan oleh kaum perempuan dipadu dengan baju kurung atau kebaya. Ukurannya bervariasi, salah satunya: ada yang berukuran $30 \mathrm{~cm}$ x $160 \mathrm{~cm}$ atau 30 $\mathrm{cm} \times 180 \mathrm{~cm}$.

3. Selendang, adalah produk kain yang dipakai menyilang dari bahu ke pinggang atau menggantung saja di bahu. Pemakainya biasanya kaum perempuan untuk menghadiri pesta, ukurannya $30 \mathrm{~cm}$ x $160 \mathrm{~cm}$ atau 50 $\mathrm{cm} \times 200 \mathrm{~cm}$.

4. Saluak, adalah jenis produk yang berfungsi sebagai penutup kepala dengan lekukan di bagian depan, umumnya yang memakai adalah kaum penghulu.

5. Bahan baju kurung.

6. Baju gadang pengantin, yang ini bersifat khusus oleh karena itu dibuat hanya kalau ada pesanan saja.

7. Tangkuluak, merupakan jenis produk yang dikhususkan sebagai penutup kepala kaum perempuan Minangkabau yang didesain menyerupai tanduk kerbau. Model tangkuluak ini sangat bervariasi, ada yang runcing tanduknya, ada pula yang tumpul tergantung daerah masing-masing.

\section{Profil Penenun dan Pengusaha Tenun Pandai Sikek}

Dari keseluruhan perajin tenun di Nagari Pandai Sikek, sebagian besar berjenis kelamin perempuan atau 90(sembilan puluh) persen lebih. Meskipun demikian, sekarang ini sudah mulai terjadi pergeseran gender dalam pekerjaan ini. Jika pada masa dahulu laki-laki dianggap tabu atau pun dicemooh jika mereka menenun, tetapi sekarang hal ini sudah dianggap biasa oleh masyarakat.

Pada masa dahulu penenun laki-laki sangat jarang, bahkan bisa dikatakan tidak ada karena menenun dianggap pekerjaan perempuan. Akan tetapi seiring dengan perkembangan zaman, maka pekerjaan ini semakin tidak mengenal perbedaan gender lagi. Masuknya penenun berjenis kelamin laki-laki di Nagari Pandai Sikek dimulai pada sekitar awal tahun 1990-an. Faktorfaktor yang mendorong mereka menekuni pekerjaan perempuan ini adalah adanya krisis ekonomi, semakin banyaknya pengangguran dan semakin sedikitnya 
lowongan kerja di sektor formal. Meskipunkaum laki-laki sudahmemasuki pekerjaan ini, tetapi persentasenya masih sangat sedikit dibandingkan kaum perempuan. Meski demikian hal ini merupakan suatu kemajuan. Sekarang ini sebagian dari para pria menekuni pekerjaan menenun ini. Pandangan masyarakat pun sudah mulai berubah. Mereka tak lagi memandang sebelah mata atau pun mencemeeh (menghina).

Usia para penenun songket profesional bisa dikatakan bervariasi dari muda hingga tua. yaitu dari umur sekitar sepuluh tahun hingga 50-an (lima puluhan) tahun. Pada umumnya anakanak gadis mulai belajar menenun ketika masih di bangku SD atau sekitar umur 10 hingga 12 tahunan. Proses belajar menjadi seorang penenun yang benar-benar mahir dan profesional dibutuhkan kerja keras dan waktu yang tidak sebentar, bisa berbulan-bulan bahkan bertahun-tahun. Anak-anak gadis di Pandai Sikek sudah dianggap mahir atau menjadi penenun yang profesional (upahan) ketika mereka berumur sekitar 17 tahunan. Itu pun biasanya baru dipercaya oleh induk tanun untuk menenun songket yang benang 3 (tiga) atau benang 4 (empat) dengan motif-motif yang tidak begitu rumit dan tidak penuh (bacatu). Alasannya adalah karena pekerjaan menenun ini hanya sekedar sebagai pekerjaan sambilan, di samping sekolah. Dalam keseharian mereka mengerjakan tenunan setelah istirahat dari pulang sekolah hingga sore hari saja. Waktu itu pun bisa berkurang apabila mereka mendapat tugas tambahan dari sekolah maupun ada kegiatan di luar jam sekolah. Oleh karena itu, waktu yang digunakan untuk menyelesaikan sehelai songket bisa jadi sangat lama. Akan tetapi hal ini disadari oleh para induk tanun karena mereka menganggap ini sebagai bagian dari suatu proses belajar dan juga proses pewarisan keterampilan menenun. Dengan demikian, para induk tanun pun hanya memberikan job (pesanan) yang tidak terlalu berat, seperti songket benang tiga atau benang empat sesuai kemampuan mereka.

Penenun yang sudah profesional atau penenun yang bisa benar-benar fokus pada pekerjaan ini dan menganggapnya sebagai mata pencaharian sebagian besar adalah ibu-ibu rumah tangga. Mereka menenun bukan sekedar hobi, tetapi memang untuk mencari uang. Selain itu sebagian lagi adalah para perempuan yang sudah tamat belajar dan untuk mencari nafkah dari menenun.

Perajin tenunan songket di Nagari Pandai Sikek dari tahun 2000 hingga tahun 2006 diketahui terus menurun (tabel 2). Dari data yang ada jumlah para penenun songket di Nagari Pandai Sikek adalah 767 orang. Beberapa hal yang menyebabkan penurunan jumlah perajin songket di nagari ini, antara lain: karena makin sedikit anak-anak muda yang tinggal di.kampung halaman. Berkurangnya anak-anak muda, terutama remaja putri, ini bisa jadi disebabkan mereka semakin disibukkan dengan tugas-tugas sekolah. Sebagian lagi dari mereka pergi merantau ke luar daerah untuk keperluan melanjutkan studi ke jenjang yang lebih tinggi, sebagian lagi karena ingin mencari pekerjaan, dan sebagian lagikarena faktor-faktor lainnya. Faktor lain adalah semakin menurunnya pemasaran kain tenun songket. Biaya pembuatan tidak sebanding penjualannya sehingga tidak bisa mencukupi kebutuhan hidup sehari-hari. Akibatnya banyak perajin tenun yang beralih profesi ke 
Tabel 2. Dinamika Perajin Tenunan Songket di Pandai Sikek per jorong

\begin{tabular}{|l|l|l|l|l|}
\hline No & \multicolumn{1}{|c|}{ Jorong } & \multicolumn{1}{|c|}{$\begin{array}{c}\text { Per Tahun } \\
2000\end{array}$} & \multicolumn{1}{|c|}{$\begin{array}{c}\text { Per Tahun } \\
2005\end{array}$} & $\begin{array}{c}\text { Per Tahun } \\
2006\end{array}$ \\
\hline $\mathbf{1}$ & Baruah & 145 & 102 & 93 \\
\hline $\mathbf{2}$ & Koto Tinggi & 298 & 266 & 242 \\
\hline $\mathbf{3}$ & Pagu Pagu & 213 & 156 & 142 \\
\hline $\mathbf{4}$ & Tanjuang & 327 & 319 & 290 \\
\hline & JUMLAH & $\mathbf{9 8 3}$ & $\mathbf{8 4 3}$ & $\mathbf{7 6 7}$ \\
\hline
\end{tabular}

(Sumber: Monografi Nagari Pandai Sikek Tahun 2007)

Tabel 3. Pengusaha/Pedagang Tenunan Songket Pandai Sikek

\begin{tabular}{|l|l|l|l|l|}
\hline \multirow{2}{*}{ No } & \multirow{2}{*}{ Jorong } & \multicolumn{3}{|c|}{ Tahun } \\
\cline { 3 - 5 } & & $\mathbf{2 0 0 0}$ & $\mathbf{2 0 0 5}$ & $\mathbf{2 0 0 6}$ \\
\hline $\mathbf{1}$ & Baruah & 17 & 10 & 9 \\
\hline $\mathbf{2}$ & Koto Tinggi & 11 & 11 & 7 \\
\hline $\mathbf{3}$ & Pagu Pagu & 3 & 4 & 4 \\
\hline $\mathbf{4}$ & Tanjuang & 12 & 13 & 11 \\
\hline & Jumlah & 43 & 38 & 31 \\
\hline
\end{tabular}

(Sumber: Sensus Ekonomi Nagari Pandai Sikek tahun 2006)

bidang lain, seperti bertani, berdagang, dan sebagainya.

Penurunan jumlah perajin tenun songket pada akhirnya diikuti oleh penurunan jumlah pengusaha/pedagang. Dari data Monografi Nagari Pandai Sikek Tahun 2007 diketahui bahwa pengusaha/pedagang tenun di nagari ini telah berkurang sebanyak dua belas orang (lihat tabel 3).

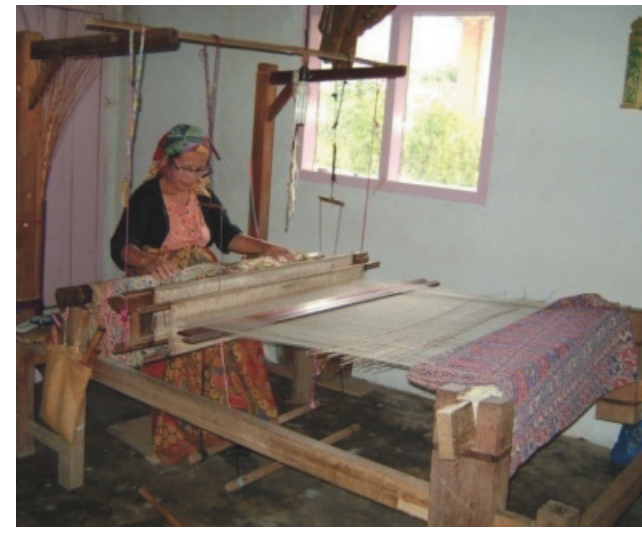

Gambar 1. Perajin tenun di Pandai Sikek menenun dengan menggunakan panta 


\section{Proses Pembelajaran dalam Pola Pewarisan}

Seorang gadis di Nagari Pandai Sikek dituntut untuk pandai menenun songket pada masa dahulu, seperti tertuang dalam pepatah Minang: "Anak padusi harus tahu di liang karok dan di suduik kampieh." Yang dimaksud dengan karok adalah alat pembagi benang atas dan bawah yang digunakan untuk membuat motif dalam bertenun. Sedangkan "Tahu di suduik kampieh" artinya bisa menganyam kampieh atau tempat nasi (bakul) yang terbuat dari anyaman daun pandan. Jadi keterampilan bertenun dan menganyam bisa dikatakan keterampilan wajib yang harus dimiliki setiap gadis di Pandai Sikek. Kepandaian ini dimaksudkan agar setelah menikah mereka bisa ikut membantu suami menambah penghasilan rumah tangga dengan cara menenun dan menganyam.

Di beberapa wilayah nagari di ranah Minang, pada masa lampau kepandaian menenun songket merupakan salah satu syarat yang tidak "tertulis'untuk menyatakan seorang gadis sudah dewasa dan sudah pantas untuk dinikahkan. Selain itu kepandaian bertenun bagi seorang perempuan dapat dijadikan bekal keterampilan untuk masa depannya. Oleh karena itu melakukan kegiatan menenun bagi perempuan di Minangkabau tidak saja dipandang memiliki keahlian yang istimewa, tetapi juga dapat dijadikan bekal dalam mengatasi masalah ekonomi (Jupriani dalam Bart, 2006: 64).

Dalam khasanah adat Minangkabau ada yang disebut dengan "Kato nan ampek"yaitu: kato mandaki, kato melereng, kato manurun, dan kato mandata. Sementara itu dalam kehidupan masyarakat di Nagari Pandai
Sikek yang dimaksud dengan kato nan ampek dikenal dalam dua versi. Versi yang pertama adalah seperti yang telah disebutkan, sedangkan versi yang ke dua berkaitan dengan kegiatan kewanitaan. Kemungkinan ini karena Minangkabau menganut garis matrilineal (garis keturunan mengikuti garis ibu) sehingga kaum perempuan mendapatkan perhatian besar dalam adat Minangkabau. Isi dari versi kedua kato nan ampek yang dipahami oleh masyarakat Nagari Pandai Sikek adalah: "Tau jo takok baniah, tahu jo suduik kampieh, tau jo liang karok, dan tau jo atah ${ }^{5}$ takunyah." Arti kalimat tersebut yaitu setiap perempuan di Pandai Sikek diharapkan memiliki keterampilan untuk bertani (menabur benih), menganyam, menenun, dan memasak. Tuturan tersebut sepertinya menegaskan bahwa kepandaian menenun merupakan salah satu hal yang tidak dapat dilepaskan dari kehidupan kaum perempuan di nagari ini. ${ }^{6}$

Sampai hari ini Pandai Sikek masih merupakan salah satu sentra tenun di Sumatera Barat yang bisa dikatakan masih bertahan. Hal ini tentu didukung oleh adanya sistem transfer of skill (pewarisan keahlian/keterampilan) di dalam masyarakat itu sendiri.

Sistem transfer of skill itu sendiri bagi masyarakat Pandai Sikek merupakan hal yang sangat penting dan sangat diperhatikan, terbukti masih banyak anak-anak terutama gadis-gadis yang belajar bertenun, bahkan ada beberapa

5 Atah adalah beras yang masih berkulit yang kadang-kadang masih tercampur dengan beras yang sudah bersih dari kulit.

6 Wawancara dengan Hj.Sanuar (80 tahun), di Jorong Baruah, Pandai Sikek, tanggal 12 April 2009 
di antara mereka yang sudah menerima pesanan dari induak tanun meskipun itu dikerjakan di sela-sela kesibukan sekolah. Ini seperti diungkapkan oleh seorang informan Yanti (16 tahun) yang masih duduk di bangku SMU kelas $2^{7}$ :

"Saya belajar bertenun sejak umur sebelas tahun ketika masih kelas V SD. Tertarik bertenun karena sering melihat uni dan amak menenun. Kemudian saya minta diajari bertenun oleh amak."

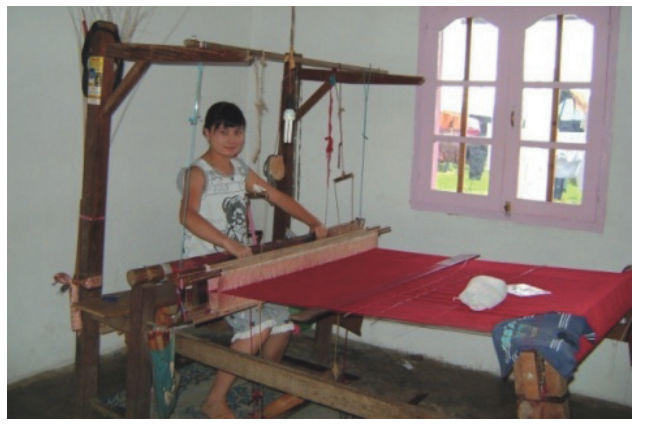

Gambar 2. Yanti (umur 16 tahun), salah satu generasi penerus perajin tenun di Pandai Sikek.

Aktivitas orang bertenun adalah pemandangan sehari-hari di Nagari Pandai Sikek, dengan melihat itu timbul keinginan anak-anak di nagari ini untuk mempelajari cara-cara bertenun. Apalagi dengan bertenun, mereka juga bisa menghasilkan uang. Pada umumnya anak-anak mulai belajar bertenun ketika masih duduk di bangku sekolah dasar. Akan tetapi meskipun demikian ada juga orang yang belajar menenun ketika

7 Wawancara dengan Yanti (16 tahun), di Jorong Pagu pagu, Pandai Sikek, tanggal 13 April 2009. sudah dewasa, bahkan sudah berkeluarga dan mempunyai dua anak, seperti diungkapkan oleh One (50 tahun) ${ }^{8}$ :

"One dulu ketika belajar batanun di Siko setelah pulang kampung dari merantau di Pekanbaru dan sudah mempunyai dua anak. Yang mengajari One dulu adalah adik One yang sudah lebih dulu pandai batanun."

Sebenarnya tidak ada batasan umur untuk mempelajari keterampilan bertenun. Akan tetapi pada umumnya anak-anak Pandai Sikek belajar bertenun ketika mereka masih anak-anak di usia remaja, yaitu sekitar umur 8 hingga 12 tahun atau ketika masih duduk di bangku sekolah dasar (SD). Apabila yang bertenun sudah berumur dewasa biasanya mereka adalah orang yang merantau keluar daerah, barulah ketika mereka pulang kembali ke kampung, mereka baru mulai belajar menenun, contohnya One. Selain itu orang yang belajar menenun di usia yang sudah dewasa biasanya adalah wanita yang bukan berasal dari Pandai Sikek lalu menikah dengan pria warga asli Pandai Sikek.

Dalam proses transfer of skill pewarisan keterampilan menenun ini masyarakat Pandai Sikek hanya dilakukan secara personal, yaitu secara perseorangan, misalnya dari orang tua kepada anak, dari kakak ke adik, dari tetangga ke tetangga dalam kewilayahan nagari ini tentunya. Dalam proses transfer of skill ini mereka tidak mengenal adanya pendidikan formal maupun semi

8 Wawancara dengan One (50 tahun), di Jorong Kototinggi, Pandai Sikek, tanggal 13 April 2009 
formal, seperti sekolah atau pun lembaga pendidikan.

\section{Agen Pewarisan Seni Menenun}

Dalam proses pewarisan keterampilan menenun (transfer of skill) terdapat dua peran penting, yaitu pelaku pewarisan dan ahli waris. Pelaku pewarisan adalah orang yang berperan aktif dalam proses transfer of skill atau pewarisan keahlian atau keterampilan kepada pihak yang berhak. Pelaku utama dalam dalam proses ini tentu semua warga Nagari Pandai Sikek itu sendiri, khususnya warga yang telah memiliki keterampilan atau keahlian menenun kain songket. Jika dirinci lebih lanjut para agen pewaris tersebut antara lain: 1) keluarga, terdiri dari setiap anggota rumah tangga yang menguasai keterampilan menenun ini, bisa orang tua, kakak, adik, 2) kerabat (orang yang berhubungan darah), 3) tetangga atau warga Pandai Sikek umumnya. Para agen pewaris keahlian menenun bisa dikatakan adalah orang paling bertanggung jawab terhadap keberlangsungan proses transfer of skill menenun.

Ahli waris yang paling berhak menerima transfer of skill adalah warga asli yaitu seseorang yang nenek moyangnya (ninik mamaknya) berasal dari nagari Pandai Sikek. Meskipun demikian terdapat pengecualian khusus dalam hal transfer of skill bagi orang luar nagari berdasarkan konvensi adat yang berlaku sejak lama turun temurun. Berdasar konvensi adat tersebut, orang luar yang dimungkinkan, yaitu: a) seseorang yang sudah diakui sebagai warga Nagari Pandai Sikek dengan cara malakok $^{9}$, b) seseorang yang mempunyai

9 Proses masuknya seseorang menjadi hubungan perkawinan dengan warga asli Nagari Pandai Sikek, c) seseorang yang diangkat menjadi anak angkat oleh warga Pandai Sikek.

Bagi orang yang sudah menetap lama dan sudah dianggap oleh masyarakat setempat sebagai warga asli Pandai Sikek atau malakok, bagi warga Pandai Sikek diijinkan untuk mempelajari keterampilan bertenun. Hal ini mungkin saja terjadi karena dia sudah berpuluhan tahun tinggal di nagari ini sehingga bergaul akrab dengan warga asli. Selain itu orang tersebut menunjukkan sikap serta perilaku yang baik terhadap warga setempat. Dengan demikian dia sudah diterima dan menjadi bagian dari masyarakat setempat. Dengan alasanalasan tersebut akhirnya warga pun tak keberatan dan tak mempermasalahkan apabila dia mempelajari cara bertenun dari warga Pandai Sikek. Hanya saja setelah dia menguasai cara bertenun, syarat yang harus dipegangnya adalah tidak mengajarkan kepandaian tersebut kepada orang luar atau orang yang bukan warga Pandai Sikek, sebagaimana peraturan tersebut juga dipegang oleh warga Pandai Sikek lainnya secara turuntemurun.

Orang luaryang juga diperbolehkan mempelajari keterampilan bertenun adalah orang yang menikah dengan penduduk asli Pandai Sikek. Dengan menikah dengan penduduk asli otomatis dia diterima sebagai bagian dari warga Pandai Sikek. Hal ini dipandang baik oleh warga, karena keterampilan ini bisa dijadikan sebagaicarauntuk mendapatkan penghasilan sehingga membantu untuk menghidupi keluarga.

warga masyarakat dengan syarat-syarat tertentu 


\section{Syarat-syarat dalam Pewarisan Keterampilan}

Dalam proses belajar mengajar menenun masyarakat di Nagari Pandai Sikek mempunyai cara unik khususnya untuk persyaratan belajar yang harus dipenuhi oleh "sang murid" atau orang yang mau belajar menenun. Ada perjanjian antara guru (yang mengajar) dengan murid (yang diajari) atau disebut membayar mahar. Mahar atau syaratsyarat yang harus disiapkan oleh si murid yang ingin belajar menenun, antara lain:

a. Beras satu gantang ${ }^{10}$ penuh, lubang atas dan lubang di bawahnya. Yang di maksud lubang di atas adalah ukuran yang dipakai untuk mengukur berat satu gantang, sedangkan lubang di bawah adalah lubang yang fungsinya sebagai kaki ukuran. Lubang bawah ini mulutnya menghadap ke bawah juga. Lubang bawah ini pun harus diisi beras hingga penuh juga. Beras ini lalu ditaruh di dalam suatu wadah, misalnya baskom.

b. Sejumlah tertentu uang (tergantung kesepakatan murid dengan guru)

c. Sirih dan pinang

d. Bunga saripati (terdiri dari berbagai bunga atau bunga rampai).

e. Rokok satu batang(tergantung kesepakatan).

10 Gantang adalah ukuran beras yang biasa digunakan di ranah Minang, yaitu sekitar $1,3 \mathrm{~kg}$.

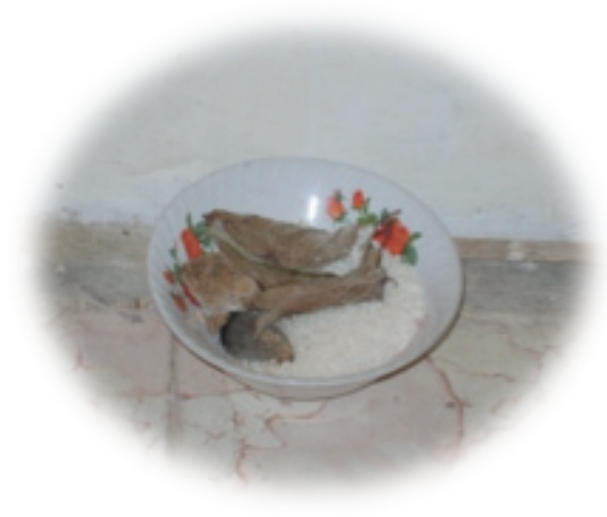

Gambar 3.

Salah satu persyaratan untuk belajar menenun atau, pada sebagian orang, bisa juga sebagai perlengkapan untuk menenun supaya mendapat kelancaran

Seluruh perlengkapan persyaratan itu ditaruh pada suatu wadah dan diletakkan di bawah panta tempat menenun. Semua persyaratan tersebut masing-masing mempunyai makna. Beras melambangkan menenun adalah suatu pekerjaan yang dapat dijadikan sebagai cara untuk mendapatkan uang atau merupakan alat untuk mencari nafkah. Artinya sumber kehidupan sang perajin tidak akan kekurangan. Sirih dalam adat Minangkabau melambangkan keramahtamahan atau lambang persetujuan (minta izin untuk memulai sesuatu). Sirih kadang disuguhkan kepada tamu terhormat untuk menghormatinya atau artinya dia diterima oleh sang tuan rumah. Dalam konteks ini sirih bisa berarti telah terjadi kesepakatan antara guru dengan murid. Uang melambangkan bahwa setelah bekerja pasti akan memperoleh upah atau hasil dari jerih payah, sebagai wujud penghargaan dari jasa yang telah diberikan. 
Semua persyaratan itu diletakkan di bawah panta tempat menenun sampai sang murid lulus atau bisa menenun. Biasanya seorang murid tersebut belajar hingga pandai menenun memerlukan waktu yang lama, bisa berbulan-bulan. Karena memakan waktu yang lama, maka beras yang diletakkan di bawah panta tersebut sering diganti-ganti sekitar 15 hari sekali dengan yang baru sebelum beras rusak karena terlalu lama disimpan. Setelah siswa yang belajar tersebut "lulus"dan menghasilkan sebuah karya tenunan, maka hasil tenunannya yang pertama tersebut diberikan kepada sang guru sebagai tanda terima kasih karena sudah memberikan keterampilan (kepandaian) menenun. Sedangkan beras yang biasa diletakkan di bawah pantalalu dimasak dan dimakan bersama. Jadi beras tersebut digunakan untuk acara "pesta kecil" syukuran atas kelulusan.

Persyaratan belajar menenun yang unik tersebut hingga sekarang masih berlaku. "Guru" yang dimaksud adalah orang yang mengajarkan atau mewariskan keterampilan menenun, seperti: orang tua, kakak, teman, saudara, tetangga, dan sebagainya. Siapapun 'guru' tersebut, dia berhak menerima upahnya, meski dia adalah orang tua kandung dari si "murid". Pada beberapa orang, bahkan ketika mereka sudah pandai menenun, mereka masih memakai sesajian yang diletakkan di bawah panta tempat menenun. Alasannya adalah supaya dalam menenun mereka mendapatkan kelancaran, tidak ada gangguan kesehatan, seperti pusingpusing atau sakit yang lain, karena dalam menenun sangat dibutuhkan ketekunan dan ketelitian.

\section{Pelarangan dalam Pola Pewarisan}

Bagi masyarakat Pandai Sikek keterampilan(keahlian)menenun songket merupakan suatu pusako (harta pusaka) yang harus dijaga dan dilestarikan dengan sepenuh hati. Pusako tersebut sesuai dengan pesan nenek moyang pendahulu mereka. Kata pusako atau pusaka mempunyai arti yang lebih dari sekedar dijaga dan dilestarikan, kata ini juga berarti dijaga dengan sebaik-baiknya dan tidak boleh diberikan kepada orang lain(dalam hal ini orang luar Pandai Sikek). Bagi masyarakat Pandai Sikek, mengajarkan cara bertenun kepada orang luar Pandai Sikek sama saja dengan menjual pusaka, jika hal ini dilakukan maka akan berakibat fatal terhadap orang yang mengajarkan tersebut. Dalam petitih orang Minang hal tersebut digambarkan seperti: "ka ateh indak bapucuak, ka bawah indak baurek, di tangah-tangah dilariak kumbang" (artinya: ke atas tidak berpucuk, ke bawah tidak berakar, di bagian tengah dilubangi oleh kumbang).. Arti pepatah tersebut ditujukan kepada orang Pandai Sikek yang telah berani melanggar peraturan adat setempat dengan mengajarkan keterampilan bertenun kepada orang luar Pandai Sikek. Si pelanggar tersebut diibaratkan seperti pohon yang pucuknya mati, akarnya layu, serta batangnya dimakan oleh hewan ngengat.

Mengajarkan menenun kepada orang luar Nagari Pandai Sikek diibaratkan seperti menjual tanah atau sawah yang pada awalnya diolah dengan susah payah dan kerja keras oleh para nenek moyang. Sawah tersebut diperoleh dengan cara manaruko ${ }^{11}$ kemudian untuk

11 Manaruko artinya membuat lahan yang sama sekali belum diolah menjadi suatu persawahan atau perkampungan 
mengairi sawah tersebut dicari sumber air dari puncak gunung, selain itu juga diusahakan dengan segala upaya untuk mengalirkannya ke sawah tersebut agar dapat ditanami dan tumbuh subur. Pada intinya semuanya itu diperoleh dengan daya upaya, tenaga untuk kesejahteraan anak cucu dan keturunannya. Mengingat semuanya itu, maka jika ada keturunan yang menjual warisan tersebut, maka orang itu akan mengalami celaka dan mendapatkan sial.

Pelarangan mengajarkan keterampilan (transfer of skill) menenun ke orang luar sudah dipegang masyarakat Pandai Sikek sejak dulu. Hal ini menjadi suatu konvensi adat di tengah-tengah masyarakat pendukungnya dan masih dipegang teguh hingga sekarang ini. mereka sangat percaya jika hal ini dilanggar, maka si pelanggar akan mendapat musibah. Meskipun demikian pernah terdapat suatu kasus pelanggaran yang dilakukan oleh Ny. M. Peristiwa ini terjadi pada tahun 1987, yaitu ketika industri kerajinan di wilayah ini bisa dikatakan pada masa puncak seiring dengan dicanangkannya Pandai Sikek sebagai daerah tujuan wisata (DTW). Banyaknya pesanan songket dari dalam maupun luar kota datang kepada para perajin setempat membuat para perajin kewalahan memenuhinya. Untuk mengatasi masalah itu Ny. M bermaksud untuk merekrut anggota baru dari luar nagari dan mengajarkan teknik menenun songket Pandai Sikek. Lama-kelamaan apa yang dilakukannya tersebut terdengar oleh warga Pandai Sikek yang lain, sehingga banyak warga memprotes tindakannya tersebut. Puncaknya dia diusir dari kampung dan rumahnya dibakar warga. Sampai hari ini sisa-sisa puing rumahnya masih ada tanpa ada yang mengurus. Ny. M sendiri akhirnya pergi dan menetap di Halaban, Kabupaten Limapuluh Kota, di sana dia terus mengembangkan kerajinan tenun songket hingga sekarang.

Dalam proses transfer of skill ini mereka tidak mengenal adanya pendidikan formal maupun semiformal, seperti adanya sekolah atau pun lembaga pendidikan. Oleh karena itu ketika akan didirikan semacamsekolah menenun, warga sangat keberatan bahkan melarang. Lembaga pendidikan yang pernah akan didirikan di Nagari Pandai Sikek adalah sekolah tenun, hanya saja warga nagari sangat menentang adanya sekolah ini. Alasannya karena sudah melanggar konvensi adat yang sudah mereka pegang sejak dulu kala secara turun temurun. Mereka khawatir bahwa dengan adanya sekolah menenun maka orang-orang luar Nagari Pandai Sikek pun nantinya bisa dengan bebas mempelajari keterampilan bertenun khas Pandai Sikek. Sementara pesan nenek moyang, keterampilan menenun ini tidak boleh diajarkan orang luar nagari.

Sekolah tenun ini sejatinya merupakan ide dari istri wakil presiden Jusuf Kalla, yaitu Ibu Mufidah Kalla yang masih keturunan darah Minangkabau. Alasan utamanya karena beliau ingin melihat dan mengembangkan sentra tenun Pandai Sikek supaya lebih maju dari yang sekarang, tetapi rupanya hal ini tidak disetujui dan tidak bisa diterima oleh warga setempat. Akhirnya sekolah tenun tersebut awalnya akan menempati gedung bekas SD Inpres yang sudah tidak digunakan dan gedung tersebut sudah selesai direnovasi. Oleh karena warga menolak sekolah tenun tersebut akhirnya sekolah tenun tersebut diubah menjadi Pusat Inovasi Tenun Pandai 
Sikek (PITPS) yang pengelolaannya melibatkan warga setempat termasuk materi yang digunakan untuk pelatihan disesuaikan dengan kebutuhan warga. Bagi masyarakat Pandai Sikek belajar bertenun tidak perlu di bangku sekolah tapi bisa di rumah secara personal saja. Alasan lain karena dengan dibangunnya sekolah tenun artinya belajar menenun akan terbuka bagi semua orang termasuk orang luar Pandai Sikek.

\section{PENUTUP}

Seni menenun kain songket hingga sekarang masih bertahan pada masyarakat Nagari Pandai Sikek. Keterampilan ini diwariskan oleh nenek moyang sudah sejak lama dan hal itu berlangsung secara turun temurun menjadi suatu pola yang tetap. Kegiatan menenun merupakan aktivitas sehari-hari di rumah khususnya dan hampir di setiap rumah di dalam nagari ini. Oleh karena itu, tidaklah mengherankan jika pewarisan seni terjadi di dalam keluarga secara nonformal. Dengan kata lain, keluarga merupakan agen terpenting dalam proses pewarisan seni menenun.

Tokoh-tokoh lain yang berperan penting (agen) dalam pola pewarisan seni menenun, antara lain orang-orang di dalam kehidupan keluarga, seperti ibu, kakak perempuan. Mereka adalah orang terdekat yang umumnya memiliki keahlian menenun. Selain itu adalah kerabat atau keluarga di luar keluarga inti dan warga Nagari Pandai Sikek pada umumnya. Pada intinya yang menjadi agen dalam pola pewarisan seni menenun di Pandai Sikek adalah warga asli Pandai Sikek. Pewarisan seni menenun ini dalam prosesnya memerlukan pembelajaran yang membutuhkan waktu berbulanbulan bahkan bertahun-tahun hingga seseorang menguasai keterampilan tersebut. Selain itu terdapat persyaratan yang disebut mahar yang hingga kini masih berlaku.

Masih bertahannya Pandai Sikek sebagai sentra tenun di Sumatera Barat merupakan hal yang positif. Meskipun demikian terdapat hal yang perlu diperhatikan, yaitu:

1. Perlunya pengayaan motif-motif pada tenunan songket karena makin berkurangnya motif-motif lama yang cenderung lebih rumit.

2. Tidak banyak lagi generasi muda yang membuatnya.

3. Pembatasan-pembatasan yang sudah menjadi konvensi adat setempat dalam proses pewarisan, seperti hanya warga Pandai Sikek yang diperbolehkan mempelajari cara menenun merupakan salah satu hambatan bagi kemajuan tenun songket di daerah ini sendiri untuk ke depannya.

4. Banyak warga yang semakin disibukkan oleh kegiatan lain, seperti melanjutkan studi, atau merantau ke luar daerah.

\section{DAFTAR SUMBER}

\section{A. Buku dan artikel}

Bart, Bernhard (ed.). 2006 Revitalisasi Songket Lama Minangkabau. Padang: Studio Songket Erika Rianti. 
Utama, Edy. 2006.

"Songket dalam Perjalanan Budaya Minangkabau (Sebuah Pengantar)", dalam Bernhard Bart (ed.), Revitalisasi Songket Lama Minangkabau. Padang: Studio Songket Erika Rianti. Halaman: 7 - 15

Koentjaraningrat et al., 2003

Kamus Istilah Antropologi. Jakarta: Progress kerjasama dengan Pusat Bahasa Depdiknas

Haviland, William A. 1988

Antropologi Jilid 2, Erlangga: Jakarta

Horton, Paul B dan Hunt, Chester L. 1987

Sosiologi Jilid 1. Jakarta: Erlangga

Jupriani. 2006.

"Songket Minang dalam Ruang Globalisasi", dalam Bernhard Bart (ed.), Revitalisasi Songket Lama Minangkabau. Padang: Studio Songket Erika Rianti. Halaman: $43-50$

\section{B. Wawancara}

Hj.Sanuar (80 tahun), di Jorong Baruah, Pandai Sikek, tanggal 12 April 2009

Yanti (16 tahun), di Jorong Pagu pagu, Pandai Sikek, tanggal 13 April 2009

One (50 tahun), di Jorong Koto Tinggi, Pandai Sikek, tanggal 13 April 2009 